Available online at:

http://journal.unila.ac.id/index.php/tropicalsoil

DOI: $10.5400 /$ jts.2019.v24i1

\title{
Soil Fertiity Properties and Rice Biomass Production Under Three Rice Farming Systems at Vertisols Sambung Macan Sub District, Sragen Regency
}

\author{
Sukristiyonubowo*1), Damasus Riyanto ${ }^{2)}$ and Sugeng Widodo ${ }^{2)}$ \\ ${ }^{1}$ Soil Research Institute, Indonesian Agency for Agricultural Research and Development, Jln Tentara Pelajar 12 \\ Bogor, *e-mail:sukristiyonuboworicky@yahoo.com, Indonesia \\ 2) Jogyakarta Assessment Institute for Agricultural Technology, IndonesianAgency for Agricultural Research and \\ Development,Jalan Stadion Maguwohardjo 22 Karang Sari, Sleman, D.I.Jogyakarta, Indonesia
}

Received May 8, 2018; Revised November 29, 2018; Accepted January 4, 2019

\begin{abstract}
The farmers realize that green revolution technology with high inputs is no longer sustainable. They want to move to other rice farming systems. The aim of research was to study soil chemical-physical characteristics and rice productions under three rice farming systems. This study was conducted in Vertisols at Sambung Macan Sub District, Sragen Regency, arranged in a randomized complete block design with three replications and as the treatments was an organic, semi organic and conventional rice systems. One kilo gram composites soil samples of $0-20 \mathrm{~cm}$ in depth were collected from five random sampling points of every site and taken in March 2017, before soil preparation. Rice biomass productions namely rice grains, rice straw and rice residues were harvested in the end of June 2017. The results indicated that in organic field, the soil chemical-physical fertility was superior to that of in semi organic and conventional and semi organic system was better than conventional in terms of soil $\mathrm{pH}$, organic $\mathrm{C}$ and total $\mathrm{N}, \mathrm{P}$ and $\mathrm{K}$ total, soil bulk density, particle density, soil porosity and permeability. Similar finding was observed for rice biomass productions. The rice grains yields were $7.53 \pm 0.85,6.60 \pm 0.15$ and $5.77 \pm 0.71$, rice straw were $7.97 \pm 0.47,7.63 \pm 0.21$ and $6.93 \pm 0.25$ and forrice residues were $4.20 \pm 0.10,3.30 \pm 0.20$ and $3.25 \pm 0.35 \mathrm{Mgs} \mathrm{ha}^{-1}$ season $^{-1}$ in organic, semi organic and conventional systems, respectively.Compared to the conventional system, the organic increased about $31 \%, 15 \%$ and $29 \%$ for rice grains, rice straw and rice residues, respectively. Comparing semi organic to conventional, the improvement was $14 \%, 10 \%$ and $2 \%$ for rice grains, rice straw and rice residues, respectively. This short term research concluded that organic rice farming was superior to both semi organic and conventional systems, but the long term effect of organic need to be further evaluated.
\end{abstract}

Keywords: Conventional rice farming system, organic, rice biomass production semi organic, soil fertility

\begin{abstract}
ABSTRAK
Petani menyadari bahwa teknologi revolusi hijau dengan masukan yang tinggi itu tidak lumintu, sehingga mereka ingin beralih ke budi daya padi yang lain. Tujuan dari penelitian ini adalah untuk mempelajari karakteristik sifat kimia fisika tanah dan produksi biomasa padi dari ketiga budi daya padi di Kabupaten Sragen. Penelitian dilakukan pada tanah Vertisol di Kecamatan Sambung Macan, Kabupaten Sragen. Percobaan disusun berdasarkan rancangan acak kelompok yang diulang tiga kali. Sebagai perlakuan adalah budi daya padi organik, semi organik dan konvensional. Satu kilo gram contoh tanah komposit pada kedalaman $0-20 \mathrm{~cm}$ yang dikumpulkan dari lima titik pengambilan secara acak diambil pada Maret 2017 sebelum pengolahan tanah. Hasil biomasa padi termasuk gabah, jerami dan sisa sisa panen dipanen dilakukan pada akhir Juni 2017. Hasil penelitian menunjukkan bahwa pada daerah budi daya padi organik, kesuburan kimia fisika tanahnya lebih baik dibandingkan semi organik dan konvensional dan pada budi daya padi semi organik lebih unggul dari budi daya padi konvensional termasuk $\mathrm{pH}, \mathrm{C}$ - organik dan total $\mathrm{N}, \mathrm{P}$ dan $\mathrm{K}$ total, berat jenis tanah, kepadatan partikle, porositas dan permeabilitas tanah. Hasil yang sama juga terjadi pada produksi biomasa padinya. Hasil gabah berkisar antara7,53 $\pm 0,85 ; 6,60 \pm 0,15$ dan $5,77 \pm 0,71$, jerami antara 7,97 \pm 0,$47 ; 7,63 \pm 0,21$ dan $6,93 \pm 0,25$ dan untuk sisa panen antara $4,20 \pm 0,10 ; 3,30 \pm 0,20$ dan $3,25 \pm 0,35 \mathrm{Mg} \mathrm{ha}^{-1}$ musim $^{-1}$ masing masing untuk budi daya organik, semi organik dan konvensional. Dibandingkan dengan sistem konvensional, budi daya organik meningkat sebesar $31 \%, 15 \%$ and $29 \%$ untuk gabah, jerami dan sisa sisa panen.
\end{abstract}

J Trop Soils, Vol. 24, No. 1, 2019:

ISSN 0852-257X; E-ISSN 2086-6682 